\title{
Pengaruh Panjang Rantai Karbon Lipid Padat terhadap Karakteristik Nanostructured Lipid Carrier Resveratrol
}

\author{
Siti Aisiyah*, Reslely Harjanti dan Vivin Nopiyanti \\ Program Studi S1 Fakultas Farmasi, Fakultas Farmasi, Universitas Setia Budi \\ *email korespondensi : mynanda.ais@gmail.com
}

\begin{abstract}
Abstrak: Karakteristik kritis nano-structured lipid carrier (NLC) sangat dipengaruhi oleh komponen lipid padat dan lipid cair dalam sistem. Penelitian ini bertujuan untuk mengkaji pengaruh panjang rantai karbon dalam lipid padat terhadap karakteristik NLC. Resveratrol sebagai senyawa antioksidan digunakan sebagai model obat. Sebanyak 3 formula NLC dibuat dengan variasi tipe lemak padat yaitu asam stearat, asam palmitat, dan asam miristat. Lemak padat dengan loading 5\%, lemak cair dengan loading 2\%, dan Tween 80 dengan loading 4,2\% sebagai surfaktan. NLC dibuat dengan metode emulsi diikuti dengan sonikasi untuk memperkecil ukuran partikel. NLC resveratrol dikarakterisasi dengan parameter ukuran partikel, zeta potensial, efisiensi penjerapan, kecepatan pelepasan obat (fluks), dan stabilitas aktivitas antioksidan. Ketiga NLC resveratrol yang diperoleh memiliki karakteristik ukuran partikel $150-280 \mathrm{~nm}$, potensial zeta $(-4 \mathrm{mV})-(-15 \mathrm{mV})$, efisiensi penjerapan $>80 \%$, nilai fluks 0,02-0,12 $\mu \mathrm{g} \cdot \mathrm{cm}^{-2}$.menit ${ }^{-1}$, dan penurunan aktivitas antioksidan 5-8\% selama penyimpanan 30 hari. Panjang rantai karbon mempengaruhi pembentukan partikel nano dari NLC dengan hubungan parabola dan panjang rantai karbon optimum akan menghasilkan partikel dengan ukuran minimum. Zeta potensial dari ketiga formula menunjukkan perbedaan yang tidak bermakna $(p>0,05)$. Panjang rantai karbon memberikan pengaruh terhadap efisiensi penjerapan secara bermakna $(\mathrm{p}<0,05)$. Formula NLC asam palmitat memiliki fluks paling tinggi. Aktivitas antioksidan ketiga formula tidak berbeda bermakna ( $p>0,05)$.
\end{abstract}

Kata kunci: NLC; Resveratrol; Lipid padat; Nano partikel; Nano-delivery

\begin{abstract}
The Influence Carbon Chain Length of Solid Lipid on Characteristics of Resveratrol Loaded Nanostructured Lipid Carrier. Critical quality attribute of nano structured lipid carrier (NLC) was mainly affected by solid and liquid lipids in this system. This study aimed to investigate the carbon chain length of solid lipid effect on characteristics of NLC. Resveratrol as antioxydant was used as a drug model. Three NLC formulas were made with $5 \%$ of solid lipid (stearic acid, palmitic acid, myristic acid), $2 \%$ liquid lipid, and $4,2 \%$ of Tween 80 as a surfactant. NLC was prepared by emulsification method followed by sonication for reducing the particle size. Resveratrol-loaded NLC was characterized by particle size along with zeta potential, entrapment efficiency, drug release/flux, and stabilization of antioxidant activity. Resveratrol-loaded NLC had particle size in range of 150$250 \mathrm{~nm}$, zeta potential $(-4 \mathrm{mV})-(-15 \mathrm{mV})$, entrapment efficiency more than $80 \%$, flux of $0,02-0,12 \mu \mathrm{g} \cdot \mathrm{cm}^{-2} \cdot \mathrm{min}^{-1}$, and reducing the antioxidant activity of $5-8 \%$ during storage for 30 days. Carbon chain length affected the formation of nano particle of NLC and had parabolic function. Therefore, the optimized carbon chain length produced minimum of particle size of NLC. Zeta potential from all formulas were not different significantly $(p>0,05)$. Carbon chain length had significant effect on entrapment efficiency $(p<0,05)$. The NLC formula with palmitic acid had the higher flux. The antioxidant from all formulas were not different significantly $(\mathrm{p}>0,05)$.
\end{abstract}


Keywords: NLC; Resveratrol; Solid lipid; Nano particle; Nano-delivery

\section{Pendahuluan}

Nano Lipid Carriers (NLC) merupakan sistem penghantaran generasi baru dari solid lipid nanoparticles (SLN) sebagai pembawa obat memiliki bermacam-macam polimer lipid padat dan lipid cair yang dicampurkan menjadi suatu matriks inti yang distabilkan oleh surfaktan (Karamsetty et al., 2016). Karakteristik nano carrier dengan ukuran partikel 20-300 $\mathrm{nm}$ memudahkan dalam proses absorbsi, sehingga mampu meningkatkan bioavailabilitas. Sistem NLC banyak menarik perhatian bagi peneliti karena memiliki beberapa kelebihan jika dibandingkan dengan SLN. Proporsi minyak cair dalam pembentuk struktur lipid pada sistem NLC meningkatkan muatan obat ke dalam sistem, sehingga NLC ini memberikan keuntungan yang menjanjikan dibandingkan dengan SLN. Selain itu, stabilitas dalam bentuk partikel mencegah peristiwa penggabungan partikel dibandingkan dengan sistem pembawa nanoemulsi (Annisa et al., 2016).

Lipid sebagai kerangka dasar pembentuk NLC menentukan karakteristik akhir NLC, terutama pada stabilitasnya. Lipid padat lebih memiliki peran yang dominan dalam membentuk stabilitas sistem. Pengaruh dari titik lebur memberikan stabilisasi sistem carrier dari NLC. Penelitian ini mengaplikasikan pengaruh tipe lipid padat yaitu asam stearat, asam palmitat, asam miristat, dengan perbedaan panjang rantai karbon berturut-turut yaitu 18, 16, dan 14. Kombinasi dengan asam oleat sebagai lipid cair akan membentuk struktur NLC padat cair. Lipid yang tidak mempunyai ikatan rangkap akan lebih stabil, tidak mudah teroksidasi dan tidak berubah menjadi asam (Tuminah, 2009). Perbedaan titik lebur antara lipid padat dan lipid cair mempengaruhi proses kristalisasi, yang secara langsung berhubungan terhadap pembentukan fase solid-state pada permukaan partikel NLC ketika penurunan suhu. Lipid padat akan membentuk kristal lebih awal di permukaan partikel, kemudian lipid cair akan berada pada inti partikel bersama bahan aktif sehingga dapat meningkatkan loading dan stabilisasi bahan aktif (Hu et al., 2005). Lipid padat dan lipid cair akan membentuk struktur kristal yang tidak sempurna, hal ini menyebabkan matriks yang terbentuk akan memuat obat dalam jumlah yang lebih tinggi (Tetyczka et al. 2017). kemungkinan obat keluar dari sistem juga dapat dikurangi atau bahkan dihindari (Muchow et al., 2008; Müller et al., 2011). Beberapa senyawa yang tidak stabil dapat dihantarkan dengan sistem NLC ini, terutama senyawa antioksidan.

Reseveratrol merupakan antioksidan alami, turunan senyawa stibilin yang diperoleh dari biji buah anggur. Resveratrol memiliki potensi antioksidan yang tinggi sehingga perlu sistem 
yang ideal untuk menjaga aktivitas antioksidan dalam sediaan (Mappamasing 2015). Oleh karena itu, dalam penelitian ini resveratrol digunakan sebagai model obat untuk diinkorporasikan ke dalam sediaan NLC. Sejauh ini belum ada penelitian yang melihat pengaruh panjang rantai karbon lipid padat terhadap karakterisasi NLC resveratrol. Berdasarkan latar belakang tersebut maka perlu dilakukan penelitian untuk mengetahui pengaruh rasio lipid padat (asam stearat, asam palmitat dan asam miristat), asam oleat dan surfaktan (Tween 80) terhadap karakterisasi NLC resveratrol menggunakan metode emulsifikasi.

\section{Bahan dan Metode}

\subsection{Bahan}

Resveratrol (Thanen Chemical, kualitas HPLC kadar 98,26\%), asam stearate (Merck), asam palmitat (Merck), asam miristat (Merck), asam oleat (Sigma Aldrich), Tween 80 (Sigma Aldrich), DPPH (Merck), metanol (Merck), dan dapar fosfat pH 6,8 (Merck).

\subsection{Metode}

\subsubsection{Validasi metode analisis resveratrol}

Kadar resveratrol ditentukan menggunakan spektrofotometer UV-vis (Shimadzu 1800) menggunakan pelarut metanol dan dapar fosfat $\mathrm{pH}$ 6,8. Kurva kalibrasi dibuat dengan konsentrasi $0,5-8,0 \mu \mathrm{g} / \mathrm{mL}$ untuk masing-masing pelarut. Larutan seri dibaca pada panjang gelombang maksimum 306 dan $317 \mathrm{~nm}$ untuk pelarut metanol dan dapar fosfat. Kurva kalibrasi divalidasi berdasarkan International Conference on Harmonization (ICH) antara lain linearitas, akurasi, presisi, batas deteksi, dan batas kuantifikasi.

\subsubsection{Rancangan dan pembuatan formula NLC resveratrol}

NLC resveratrol dibuat dengan metode emulsi-sonikasi. Sebanyak 3 formula dengan variasi tipe lemak padat yaitu asam stearat, asam palmitat, dan asam miristat (Tabel 1). Lemak padat dengan loading 5\%, lemak cair dengan loading 2\%, dan Tween 80 dengan loading 4,2\% sebagai surfaktan.

Pembuatan NLC resveratrol diawali dengan meleburkan lipid padat dan lipid cair (asam stearat, palmitat, dan miristat dengan asam oleat) pada suhu $70-80{ }^{\circ} \mathrm{C}$, dan dipanaskan larutan surfaktan Tween 80) dengan pelarut aquadestillata yang dipanaskan pada suhu $70-80{ }^{\circ} \mathrm{C}$. Campuran surfaktan panas kemudian ditambahkan ke dalam campuran lipid panas dengan menggunakan Overhead Stirrer IKA RW 20 Digital Mixer pada kecepatan 1000 rpm selama 10 menit. Tahap selanjutnya yaitu campuran dimasukkan ke dalam sonikator (Qsonic sonicators) pada amplitudo 35\% selama 5 menit dengan pulse on 1 menit off 1 menit 
(Sriarumtias dkk., 2017). NLC yang diperoleh disimpan untuk proses analisis dan karakterisasi.

Tabel 1. Rancangan Formula NLC Resveratrol yang dibuat dengan metode emulsi-sonifikasi.

\begin{tabular}{cccc}
\hline \multirow{2}{*}{ Bahan } & \multicolumn{3}{c}{ Formula (\%) } \\
\cline { 2 - 4 } & F1 & F2 & F3 \\
\hline Resveratrol & 0,025 & 0,025 & 0,025 \\
Asam stearat & 5 & - & - \\
Asam palmitat & - & 5 & - \\
Asam miristat & - & - & 5 \\
Asam oleat & 2 & 2 & 2 \\
Tween 80 & 4,2 & 4,2 & 4,2 \\
Aquadestillata ad & 100 & 100 & 100 \\
\hline
\end{tabular}

\subsubsection{Pengamatan ukuran partikel secara mikroskopik}

Pengukuran ukuran partikel NLC resveratrol dilakukan secara kualitatif dengan menggunakan mikroskop Leica (Wetzlar, Jerman). Preparasi sampel NLC untuk pengamatan ukuran partikel secara kualitatif yaitu setelah dilakukan proses emulsifikasi sediaan diambil 1 tetes diletakkan di atas objek glass, kemudian ditetesi dengan air secukupnya ditutupi dengan deck glass, setelah proses sonikasi kemudian diambil 1 tetes diletakkan di atas object glass, kemudian ditetesi dengan air secukupnya. Masing-masing preparasi dibaca pada mikroskop pada perbesaran $40 x$.

\subsubsection{Pengukuran ukuran partikel}

Pengukuran ukuran partikel NLC resveratrol menggunakan alat pengukur ukuran partikel Malvern SZ-100 (Malvern, UK). Pengukuran dilakukan menggunakan teknik hamburan cahaya dinamis pada panjang gelombang $632 \mathrm{~nm}$, sudut $173^{\circ}$ dan indeks bias 1,333; dan serapan sampel disesuaikan dengan serapan sampel. Gate time disesuaikan dalam rentang 2,56 hingga $10,24 \mu$ s. Zeta potensial diukur menggunakan karbon cuvette pada $25^{\circ} \mathrm{C}$.

\subsubsection{Efisiensi penjerapan}

Cara pembuatan setiap sampel diambil $2 \mathrm{~mL}$, kemudian disentrifugasi pada $6000 \mathrm{rpm}$ selama 30 menit untuk memisahkan fase lipid dan air. Bagian supernatan dilarutkan dengan metanol kemudian dibaca spektrofotometer UV-VIS pada $306 \mathrm{~nm}$ (Nagalakshmi et al. 2017). Keberhasilan jebakan NLC dapat dilihat pada persamaan 1.

$$
\text { Efisiensi penjerapan }=\frac{(\mathrm{Wa}-\mathrm{Ws})}{\mathrm{Wa}} \times 100
$$

Persamaan 1. Persamaan efisiensi penjerapan. Massa obat yang ditambahkan ke dalam formula (Wa) dan analisis bobot obat dalam supernatant (Ws). 


\subsubsection{Uji pelepasan obat}

Pelepasan obat in vitro disiapkan NLC-RSV dilakukan dengan menggunakan metode dialysis bag (Membran Himedia-Dialisis 135 MWCO 12.000-14.000 Da, Mumbai, India). NLC-RSV diambil 10gram kemudian dimasukkan ke dalam dialysis bag dan kedua ujung kantung diklem. Kantung dimasukkan ke dalam chamber dengan bantuan sinker kemudian diisi dapar fosfat $500 \mathrm{~mL} \mathrm{pH} \mathrm{7,4.} \mathrm{Suhu} \mathrm{pada} \mathrm{media} \mathrm{dipertahankan} \mathrm{pada} 37 \pm 1{ }^{\circ} \mathrm{C}$ dengan kecepatan $50 \mathrm{rpm}$, kemudian disampling $5 \mathrm{~mL}$ pada interval waktu 5, 10, 15, 30, 45, 60, dan 120 dengan spuit dan diganti dengan dapar yang baru pada setiap waktu pengambilan sampling. Formulasi diambil untuk koreksi dengan spektrofotometer UV-Vis pada lamda max $317 \mathrm{~nm}$. Setiap sampling dibaca sebanyak 3 kali.

\subsubsection{Uji aktivitas antioksidan NLC resveratrol}

Pengujian aktivitas antioksidan NLC-RSV dilakukan dengan ditimbang masing-masing formula 2 gram, dimasukkan ke dalam labu ukur $10 \mathrm{~mL}$ kemudian ditambah metanol p.a sampai tanda batas, kemudian diambil 1 bagian larutan uji +1 bagian DPPH +3 bagian metanol kemudian dibaca di spektrofotometer UV-Vis pada panjang gelombang 306 dan dihitung \% inhibisi.

\subsection{Analisis data}

Data yang diperoleh dianalisa secara statistik dengan uji analysis of variance (ANOVA) dengan taraf kepercayaan $95 \%(\mathrm{p}=0,05)$.

\section{Hasil dan Pembahasan}

\subsection{Hasil validasi metode analisis}

Validasi metode analisis bertujuan untuk menghasilkan data kuantitatif yang akurat dan reprodusibel (Gandjar \& Rohman 2012). Parameter validasi dapat dilihat pada Tabel 2. Hasil penentuan linieritas menunjukkan bahwa metode analisis yang digunakan dalam penelitian, dapat memberikan respon yang secara langsung proporsional terhadap konsentrasi resveratrol dalam sistem NLC. Penentuan LOD dan LOQ bertujuan untuk mengetahui batas deteksi dan batas kuantifikasi terendah dari sampel yang masih dapat menghasilkan data dengan akurasi dan presisis yang baik. Nilai perolehan kembali yang dihasilkan adalah 100,77\% menunjukkan metode yang digunakan memiliki akurasi yang tinggi dan dan berada pada rentang 98-102\%. Hasil uji presisi menghasilkan RSD sebesar 0,96\% lebih kecil dari $2 \%$ yang menunjukkan bahwa metode yang digunakan memiliki presisi yang baik (Gandjar \& Rohman 2012). 
Tabel 2. Parameter validasi metode analisis konsentrasi resveratrol dalam system Nano Lipid Carriers (NLC).

\begin{tabular}{lc}
\hline \multicolumn{1}{c}{ Parameter } & Hasil \\
\hline Linieritas & 0,9995 \\
Batas deteksi (LOD) & $0,2755 \mu \mathrm{g} / \mathrm{mL}$ \\
Batas kuantifikasi (LOQ) & $0,8349 \mu \mathrm{g} / \mathrm{mL}$ \\
Perolehan kembali (recovery) & $100,77 \%$ \\
Simpangan baku relatif (RSD) & $0,96 \%$ \\
\hline
\end{tabular}

\subsection{Pembuatan NLC}

Pembuatan NLC dilakukan dengan teknik emulsifikasi kemudian diperkecil ukuran partikel NLC menggunakan energi eksternal dari sonikator. Hasil menunjukkan bahwa semua formula NLC resveratrol mempunyai konsistensi kental, berwarna putih susu, dan tidak memadat selama proses penyimpanan. Hasil makroskopis NLC resveratrol dapat dilihat pada Gambar 1.

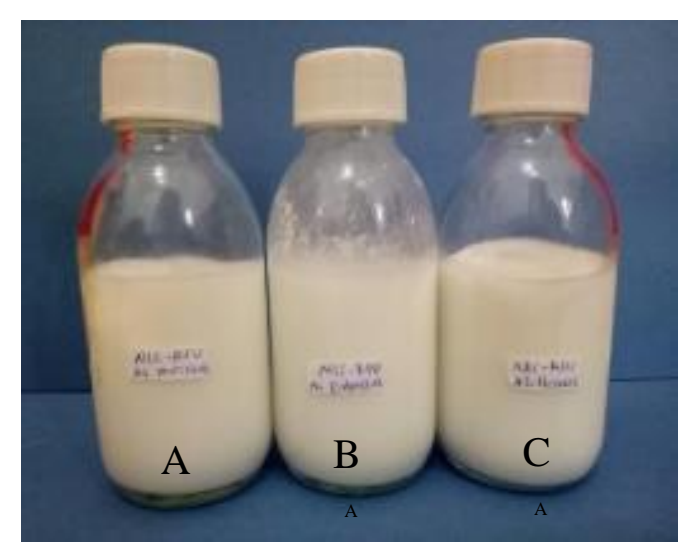

Gambar 1. Makroskopis NLC menggunakan variasi lemak padat. Asam miristat (a), asam palmitat (b) dan asam stearat (c)

Evaluasi proses pembuatan NLC diamati menggunakan mikroskop optik (Gambar 2). Hasil menunjukkan bahwa droplet emulsi terlihat jelas setelah proses emulsifikasi. Pemecahan globul-globul emulsi dilakukan dengan energi eksternal dari sonikator $(20 \mathrm{MHz})$. Secara mikroskopis, asam palmitat menghasilkan globul yang ukuran lebih besar dibandingkan asam stearat dan asam miristat, akan tetapi setelah pross sonikasi, semua formula menunjukkan hasil yang sama yaitu tidak teramati globul. Hal ini menunjukkan bahwa proses sonikasi mampu menurunkan ukuran partikel dari droplet emulsi. Setelah penyimpanan, permukaan droplet akan berubah memadat karena karakteristik dari lemak padat. Proses ini mampu meningkatkan stabilisasi partikel sistem dispers dari droplet yang terbentuk. 


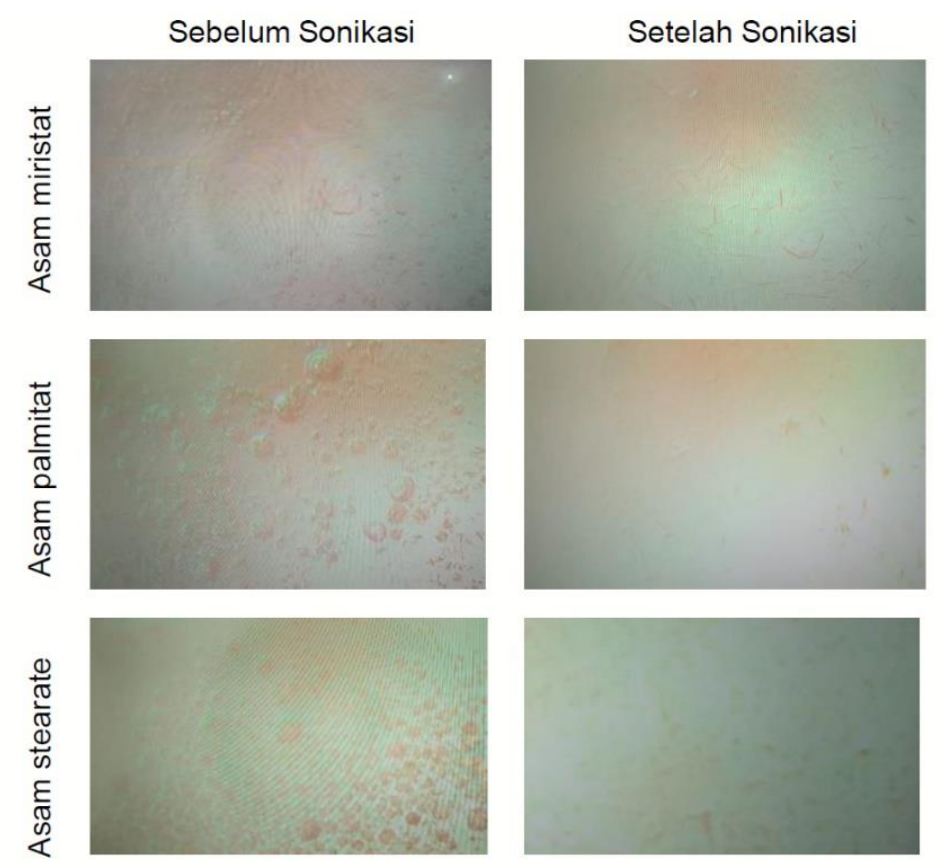

Gambar 2. Pengaruh proses sonikasi terhadap behavior globul emulsi NLC diamati menggunakan mikroskop optik

\subsection{Karakterisasi ukuran partikel dan efisiensi penjerapan NLC resveratrol}

Partikel nano berbasis lipid mampu meningkatkan bioavailabilitas dari suatu senyawa dengan sistem pembawa berukuran 20-300 nm (Carlotti et al., 2005). Modifikasi permukaan pada sistem pembawa dengan surfaktan dan lipofilisitas dari lipid mampu mengubah mekanisme transport dari suatu pembawa. Partikel merupakan parameter kristis penentu mutu dari sediaan NLC. Hasil karakterisasi ukuran partikel NLC dengan variasi tipe asam lemak dapat dilihat pada Gambar 3a. Hasil menunjukkan bahwa semua formula NLC memiliki ukuran partikel antara 150-280 nm. Asam palmitat memiliki ukuran partikel yang paling kecil $(150 \mathrm{~nm})$, sedangkan asam stearat memiliki ukuran partikel yang paling tinggi, dan asam miristat mempunyai ukuran partikel lebih rendah dibandingkan asam stearat. Hasil menunjukkan bahwa perbedaan tipe lipid padat memberikan pengaruh yang bermakna terhadap ukuran partikel $(\mathrm{p}<0,05)$. Penurunan panjang rantai karbon menurunkan ukuran partikel, akan tetapi pada asam lemak dengan panjang rantai karbon paling rendah (C-14; asam miristat) menunjukkan peningkatan ukuran partikel. Hasil ini mengkonfirmasi bahwa hubungan antara ukuran partikel dan panjang rantai karbon memiliki pola quadratic, sehingga terdapat panjang rantai karbon optimum untuk menghasilkan ukuran partikel terkecil. Hasil distribusi ukuran partikel menunjukkan bahwa semua formula memiliki bentuk distribusi monodisperse dengan nilai distribusi ukuran partikel (PDI) $<0,5$ dan tidak berbeda bermakna antara ketiga formula $(\mathrm{p}>0,05)$. 
Zeta potensial dari ketiga formula menunjukkan perbedaan yang tidak bermakna -15 $\mathrm{mV}(\mathrm{p}>0,05)$. Hal ini disebabkan karena semua formula memiliki residu asam lemak yang berkontribusi terhadap nilai zeta potensial yang paling dominan. Pengukuran zeta potensial bertujuan untuk mengetahui kestabilan sistem NLC resveratrol, karena zeta potensial berperan mengatur derajat tolak menolak antara partikel terdispersi yang bermuatan sama dan saling berdekatan (Sinko 2006). Nilai zeta potensial lebih dari $\pm 30 \mathrm{mV}$ dalam sistem nanopartikel menunjukkan bahwa sistem terbukti stabil (Mohanraj \& Chen 2006). Hasil pengukuran zeta potensial ketiga formula memiliki sistem nanopartikel yang tidak stabil. Hal ini disebabkan karena gaya tolak menolak yang lemah sehingga partikel saling bergabung dan mengendap.

Pengukuran efisiensi penjerapan bertujuan untuk mengetahui persentase resveratrol yang terjebak dalam sistem NLC. Hasil pengukuran efisiensi penjerapan menunjukkan bahwa ketiga formula memberikan hasil lebih dari $80 \%$ (Gambar 3b). Hal ini menunjukkan bahwa resveratrol yang terjebak dalam sistem NLC cukup tinggi. NLC resveratrol yang diformulasi dengan lipid padat asam palmitat mampu menjebak resveratrol paling tinggi, semakin tinggi nilai efisiensi penjerapan maka semakin bagus sistem dalam meningkatkan loading obat. Asam palmitat memiliki nilai efisiensi penjerapan yang paling tinggi diikuti oleh asam stearat dan asam miristat. Rantai lipid berperan dalam pembentukan kristal yang kurang sempurna, sehingga memberikan ruang yang lebih besar di dalam kristal. Ruang kristal yang membesar tersebut dapat mengakomodasi obat lebih besar sehingga efisiensi penjerapan yang dihasilkan semakin besar (Soute \& Muller 2007).
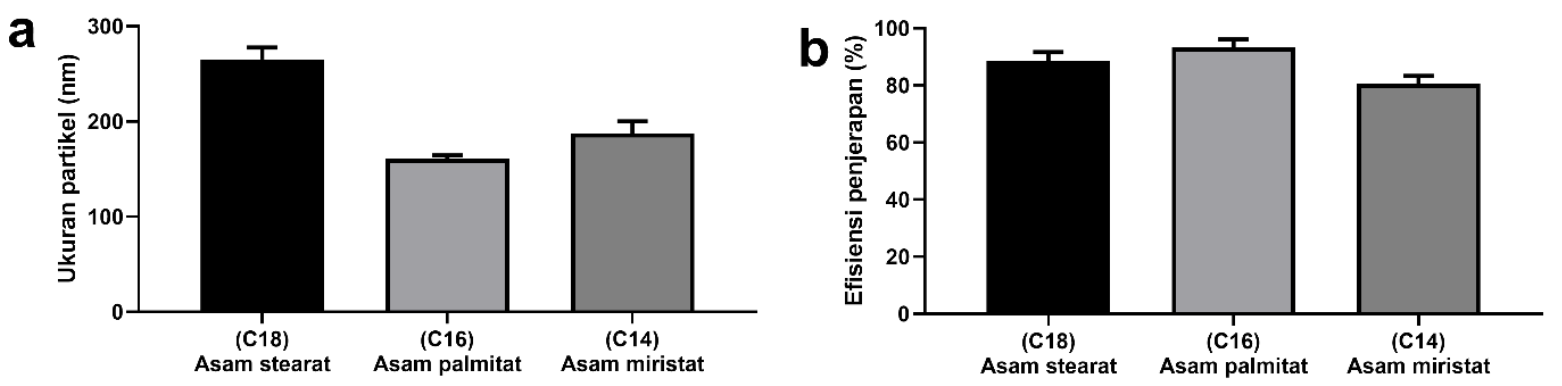

Gambar 3. Pengaruh tipe lipid padat terhadap ukuran partikel NLC resveratrol (a) dan efisiensi penjerapan NLC resveratrol (b).

Hasil menunjukkan bahwa panjang rantai karbon memberikan kontribusi terhadap efisiensi penjerapan secara bermakna $(\mathrm{p}<0,05)$. Pengaruh lipofilisitas dari lipid dan obat merupakan faktor penentu dalam nilai efisiensi penjerapan. Interaksi antara lipid dan komponen lipid lain seperti lipid cair, asam oleat dan Tween 80 sebagai surfaktan mempengaruhi jumlah obat yang dapat dienkapsulasi ke dalam sistem. Kedekatan lipofilisitas 
antara obat dan pembawa merupakan faktor kritis dan paling dominan dalam menentukan nilai efisiensi penjerapan.

\subsection{Karakteristik pelepasan NLC resveratrol}

Profil pelepasan resveratrol dari NLC resveratrol dapat dilihat pada Gambar 4a. Hasil menunjukkan bahwa semua asam lemak memiliki pola yang sama kecuali asam palmitat terdapat burst release setelah 45 menit. Asam stearat memiliki jumlah obat yang terdifusi paling tinggi dibandingkan kedua asam lemak di awal waktu, akan tetapi ketika mencapai kejenuhan membran, asam palmitat menghasilkan jumlah obat yang terdifusi lebih dinggi dibandingkan dengan asam stearat. Asam miristat memiliki jumlah obat yang dilepaskan paling rendah dibandingkan dengan kedua tipe asam lemak. Jumlah obat yang terdifusi disebabkan karena obat dalam sistem bebas dan ukuran dari partikel NLC. Membran dialisis yang digunakan bersifat sebagai barier fisik, jika partikel lebih kecil dibandingkan dari cut off membran maka dapat terdifusi. Kuantifikasi kecepatan difusi dilakukan dengan nilai fluks dari profil pelepasan NLC resveratrol. Fluks (kecepatan pelepasan) dari sistem NLC ditentukan dengan menghitung slope dari persamaan garis linier antara jumlah kumulatif obat yang terlepas dan akar waktu.
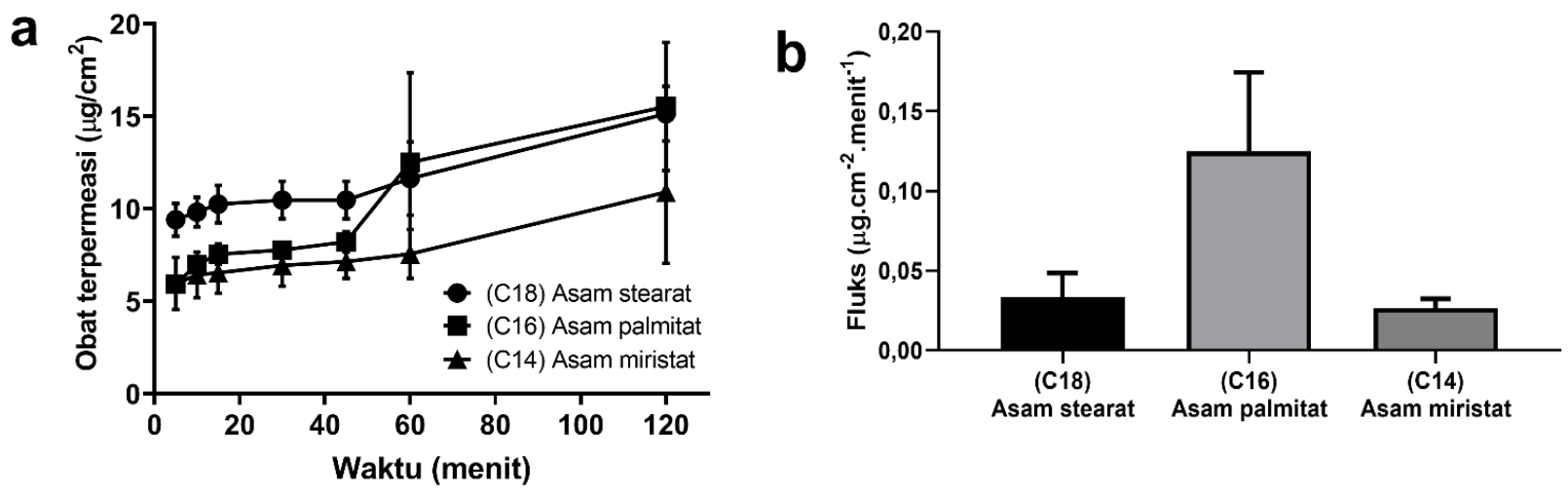

Gambar 4. Profil pelepasan resveratrol dengan metode difusi franz (a) dan nilai fluks (b).

Hasil nilai fluks disajikan pada Gambar 4b. Hasil menunjukkan bahwa asam palmitat memiliki fluks yang paling tinggi dibandingkan dengan asam stearat dan asam miristat. Hal ini dikonfirmasi oleh hasil ukuran partikel bahwa asam palmitat memiliki ukuran partikel yang paling kecil sehingga memudahkan NLC resveratrol untuk tertransport. Asam stearat dan asam miristat memiliki perbedaan yang tidak bermakna $(p>0,05)$ dari nilai kecepatan transport, akan tetapi asam stearat memiliki kemampuan transport yang lebih baik ditunjukkan dengan jumlah obat yang dilepaskan lebih tinggi dibandingkan dengan asam miristat. Secara teori laju pelepasan (fluks) dipengaruhi oleh ukuran partikel, viskositas dan 
efisiensi penjerapan (Sinko dan Singh, 2011). Semakin kecil ukuran partikel semakin luas permukaannya sehingga jumlah yang berdifusi semakin besar, tetapi ukuran partikel yang dihasilkan dari penelitian ini tidak memberikan pengaruh terhadap fluks.

\subsection{Karakteristik antioksidan NLC resveratrol}

Aktivitas antioksidan NLC resveratrol dinyatakan dalam persentase inhibisi terhadap radikal DPPH. Persentase inhibisi didapatkan dari perbedaan serapan antara DPPH dan sampel yang diukur dengan spektrofotometer UV-Vis. Pengujian aktivitas antioksidan dilakukan pada hari ke-1 dan setelah penyimpanan selama 30 hari pada suhu kamar untuk mengetahui stabilitas antioksidan. Hasil pengukuran dapat dilihat pada Gambar 5 yang menunjukkan bahwa aktivitas antioksidan dari ketiga formula tidak berbeda bermakna ( $p>0,05)$. Aktivitas antioksidan dari ketiga formula setelah proses penyimpanan selama 30 hari menunjukkan tidak ada perbedaan yang bermakna $(\mathrm{p}>0,05)$. Akan tetapi, penurunan aktivitas antioksidan dari ketiga formula menunjukkan penurunan yang bermakna $(p<0,05)$. Selama proses penyimpanan aktivitas antioksidan dari NLC resveratrol menurun dari 5-8\%. Penurunan ini disebabkan karena rusaknya senyawa antioksidan yang tidak terenkapsulasi ke dalam sistem NLC, sehingga proteksi terhadap radikal tidak dapat optimal. Hasil ini selaras dengan nilai efisiensi penjerapan bahwa, efisiensi penjerapan tinggi mampu memberikan penurunan aktivitas antioksidan yang rendah.

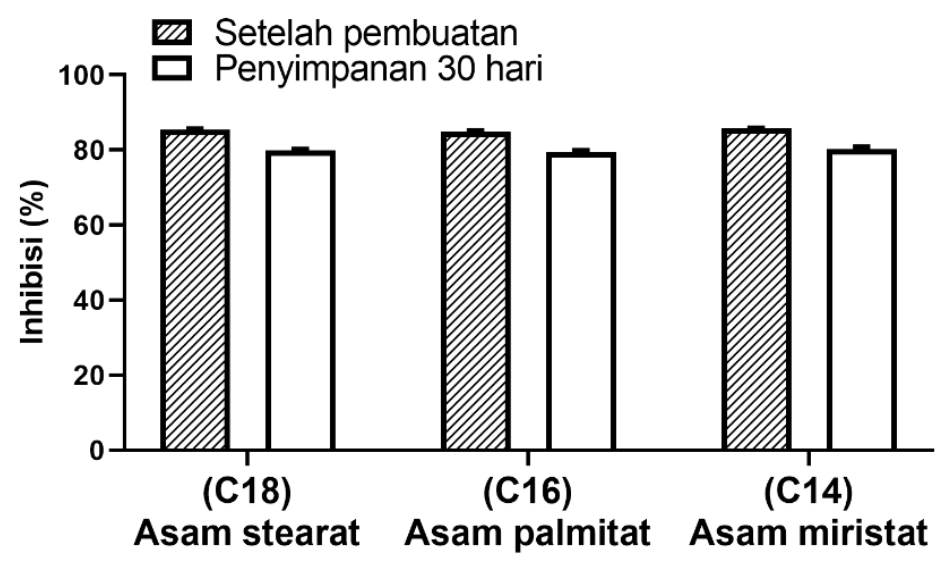

Gambar 5. Pengaruh lama penyimpanan terhadap nilai inhibisi resveratrol setelah pembuatan dan penyimpanan selama 30 hari

\section{Kesimpulan}

Kontribusi tipe lipid padat yang ditunjukkan dengan perbedaan panjang rantai karbon mempengaruhi karakteristik dari NLC resveratrol. Hubungan antara panjang rantai karbon menunjukkan pola parabola dengan ukuran partikel, sehingga terdapat panjang rantai karbon optimum untuk menghasilkan ukuran partikel yang paling kecil. Zeta potensial dari ketiga formula menunjukkan perbedaan yang tidak bermakna $(p>0,05)$. Panjang rantai karbon 
memberikan pengaruh terhadap efisiensi penjerapan secara bermakna $(\mathrm{p}<0,05)$. Formula NLC asam palmitat memiliki fluks paling tinggi. Aktivitas antioksidan ketiga formula tidak berbeda bermakna $(p>0,05)$.

\section{Ucapan Terimakasih}

Terima kasih peneliti sampaikan kepada Universitas Setia Budi yang telah membiayai penelitian ini pada skema Penelitian Dasar tahun pendanaan 2018.

\section{Daftar Pustaka}

Annisa, R., Hendradi, E., Melani, D. (2016). Pengembangan Sistem Nanostructured Lipid Carriers (NLC) Meloxicam dengan Lipid Monostearin dan Miglyol 808 Menggunakan Metode Emulsifikasi. Journal of Tropical Pharmaceutical and Chemistry, 3(3).

Gandjar, I. G. dan Rohman, A. (2012). Analisa Obat secara Kromatografi dan Spektroskopi. Yogyakarta: Pustaka Pelajar

Hu F.Q., Jiang, S.P., Yuan, H., Ye, Y.Q., Zeng, S. (2005). Preparation and characterization of stearic acid nanostructured lipid carriers by solvent diffusion method in an aqueous system. Colloids and Surfaces B. Biointerfaces, 45: 167-173.

Karamsetty, V.M., Surya Tej, Afrasim Moin, D.V., Gowda, Anjali Godugu Karunakar, Nikhil P. Patel and Samudra sai Kamal. (2016). Nano structured Lipid Carrier Based Drug Delivery System. Jefferson County Parks and Recreation Commission. 8(2):627-643.

Mappamasing, F., Anwar, E. and Mun'im, A. (2015). Formulasi, karakterisasi dan Uji Penetrasi In Vitro resveratrol Solid Lipid Nanopartikel dalam krim Topikal. Jurnal Ilmu Kefarmasian Indonesia, Universitas Indonesia, hlm. 137-144.

Mohanraj, V.J. and Chen, Y. (2006). Nanoparticle - A Review. Tropical J. of Pharmaceutical Research, 5 (1), 561-573.

Muchow, M., Maincent, P., Muller, R.H. (2008). Lipid nanoparticles with a solid matrix (SLN, NLC, LDC) for oral drug delivery. Drug Development and Industrial Pharmacy, 34, 1394-405.

Müller, R. H., Shegokar, R., Keck, C.M. (2011). 20 Years of Lipid Nanoparticles (SLN \& NLC): Present State of Development \& Industrial Applications. Current Drug Discovery Technologies, 8, 207-227.

Nagalakshmi, S., Shanmuganathan, S., Anbarasan, B. and K Sandhya. (2017). Nanostructured Lipid Carriers (NLCs): A Novel Based Nano Carrier for Drug Delivery and Drug Targeting. Advanced Journal of Pharmacie and Life science Research, 4(1), 17-24.

Sinko, P.J. (2006). Martin Farmasi Fisika dan Ilmu Farmasetika, Edisi 5. Jakarta. Penerbit Buku Kedokteran.

Sinko, P.J. and Singh, H., (ed). (2011). Martin's Physical Pharmacy and Pharmaceutical Sciences Physical Chemical and Biopharmaceutical Principles in the Pharmaceutical Sciences, 6th Ed. Lippincott Williams \& Wilkins a Wolters Kluwer Bussines, Philadelphia, $300-318$.

Soute, E.B. and Muller, R.H. (2007). Lipid Nanoparticles (Solid Lipid Nanopartocles and Nanostructured Lipid Carriers) for cosmetic, Dermal, and Transdermal Aplication. In D. Thassu, M. Deleers, \& Y. Payhak, Nanoparticulate Drug Delivery System. (pp. 213-229). New York: Informa Healthcare USA, Inc.

Sriarumtias, F.F., Darijanto, S.T., Damayanti, S. (2017). Formulasi dan uji potensi antioksidan nanostructured lipid carriers (NLC) retinil palmitat. Acta Pharmaceutica Indonesia, 42(1), 25-31. 
Tetyczka, C., Griesbacher, M., Absenger-Novak, M., Frohlich, E., Roblegg E. (2017). Development of nanostructured lipid carriers for intraoral delivery of Domperidone. International Journal of Pharmaceutics. 526(1-2), 188-198.

Tuminah, S. (2009). Efek Asam Lemak Jenuh dan Asam Lemak Tak Jenuh Trans terhadap Kesehatan. Media Peneliti dan Pengembangan Kesehatan. Vol XLX.

\section{(c) (1) ()}

2019 by the authors. Submitted for possible open access publication under the terms and conditions of the Creative Commons Attribution-ShareAlike 4.0 International (CC BY-SA 4.0) license (https://creativecommons.org/licenses/by-sa/4.0/). 